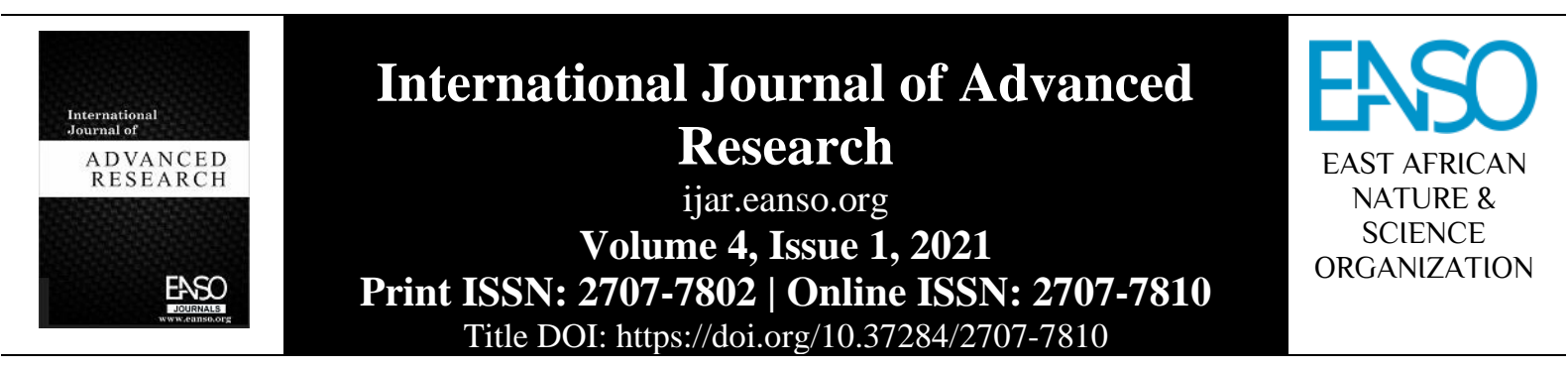

Original Article

\title{
Efficacy of Essential Oils from Ocimum kenyense as a Biopesticide against Aphis gosypii, Thrips tabaci and Bemisia tabaci.
}

\author{
Mwaura James Njuguna ${ }^{1^{*}}$, Dr. Mary Muriuki Hutchins, $P h D^{l} \&$ Dr. Samuel Karenga, PhD \\ ${ }^{1}$ Mount Kenya University, P. O. Box 342-01000, Thika, Kenya. \\ * ORCID: https://orcid.org/0000-0002-5846-6538; Author email: jnjuguna977@ gmail.com.
}

Article DOI: https://doi.org/10.37284/ijar.4.1.505

\section{Publication Date: ABSTRACT}

14 December 2021 Natural sources of biopesticides such as plants and microorganisms are

Keywords:

Ocimum Kenyense,

1, 8-Cionele,

Biopesticide,

ATR-FTIR,

LD50.

widely employed for pest management globally. Over the last five decades, the use of biopesticides has been explored as a safer alternative to synthetic pesticides. This study determined the repellence and contact toxicity of essential oils from Ocimum kenyense plant against Thrips tabaci, Bemisia tabaci, and Aphis gosypii. The essential oils (Eos) were extracted from dry leaves by hydrodistillation using the Clevenger apparatus for 8 hours. The composition of essential oils was qualitatively and quantitatively analysed using GC-MS, while ATR-FTIR was used to determine the functional groups. The major compound ion in the Eos was 1,8-Cionele while the major phytochemical identified was Eucalyptol Bioassay of the crude extracts were carried out on T. tabaci, B. tabaci, and A. gosypii. Contact toxicity and repellency tests against mixed-sex adult pests were carried out on T. tabaci, B. tabaci, and A. gosypii. In contact toxicity, five different concentrations were prepared and each was replicated five times. Acetone was used as a negative control, while permethrin, a commercial chemical pesticide was used as a positive control. The LD50 of the essential oils was determined by Probit analysis SPSS version 26.0. The response to the treatments was observed after 24 hours by using a blunt object probing and the pests that did not respond were counted as dead. It was found that essential oils from $O$. kenyense had the lowest LD50 of $0.127 \mu \mathrm{L}$ against $A$. gosypii. This implies that $O$. kenyense can be used as a contact toxicant against A. gosypii. Repellency tests were carried out at four different concentrations. N, NDiethyltoluamide (DEET) repellent from a commercial mosquito repellent was used to compare the effectiveness of the essential oils against commercial repellents. The repellency test responses were observed after 1 hour and the data was used to determine the correlation between different levels of concentration of Eos and percentage repellency of Eos of $O$. kenyense leaves carried out at $\alpha=0.05$. There was a high correlation of 1.000 between the increase in concentration of Eos and repellency against $A$. gosypii, T. tabaci and B. tabaci. The results were statistically significant and $(\mathrm{P}<0.05, \alpha=0.05)$. Therefore, essential oils from $O$. kenyense can be used as 
a contact toxicant biopesticide against $A$. gosypii and a repellent biopesticide against $A$. gosypii, T. tabaci and B. tabaci.

\section{APA CITATION}

Njuguna, M. J., Hutchins, M. M., \& Karenga, S. (2021). Efficacy of Essential Oils from Ocimum kenyense as a Biopesticide against Aphis gosypii, Thrips tabaci and Bemisia tabaci. International Journal of Advanced Research, 4(1), 14-26. https://doi.org/10.37284/ijar.4.1.505

\section{CHICAGO CITATION}

Njuguna, Mwaura James, Mary Muriuki Hutchins \& Samuel Karenga. 2021. "Efficacy of Essential Oils from Ocimum kenyense as a Biopesticide against Aphis gosypii, Thrips tabaci and Bemisia tabaci". International Journal of Advanced $R$ esearch 4 (1), 14- 26. https://doi.org/10.37284/ijar.4.1.505.

\section{HARVARD CITATION}

Njuguna, M. J., Hutchins, M. M., \& Karenga, S. (2021) "Efficacy of Essential Oils from Ocimum kenyense as a Biopesticide against Aphis gosypii, Thrips tabaci and Bemisia tabaci”, International Journal of Advanced Research, 4(1), pp. 14-26. doi: 10.37284/ijar.4.1.505.

\section{IEEE CITATION}

M. J. Njuguna, M. M. Hutchins, \& S. Karenga, "Efficacy of Essential Oils from Ocimum kenyense as a Biopesticide against Aphis gosypii, Thrips tabaci and Bemisia tabaci”, IJAR, vol. 4, no. 1, pp. 14-26, Dec. 2021.

\section{MLA CITATION}

Njuguna, Mwaura James, Mary Muriuki Hutchins \& Samuel Karenga. "Efficacy of Essential Oils from Ocimum kenyense as a Biopesticide against Aphis gosypii, Thrips tabaci and Bemisia tabaci". International Journal of Advanced Research, Vol. 4, no. 1, Dec. 2021, pp. 14-26, doi:10.37284/ijar.4.1.505.

\section{INTRODUCTION}

Chemical control is the most commonly used method of pest management that involves the use of different types of pesticides (Wei et al., 2018). Pesticides are classified using different criteria such as the chemical composition, the target pests, formulations, mode of action, and source (Pandya, 2018; Gogi et al., 2017). Concerning sources, they are classified as either synthetic or biopesticides (Kavit \& Jain, 2013). Kumar (2012) defines biopesticides as substances that occur naturally and are used to control pests in non-toxic mechanisms and eco-friendly manner (Kumar, 2012). The term biopesticide is therefore taken as a generic term for pest control strategies that utilise bioactive microbes from animals, bacteria, viruses, and plants for sustainable agriculture (Ivase et al., 2017).

Biopesticides are further divided into three classes, namely, plant-incorporated protectants (PIP), microbial, and biochemical pesticides (Kareru et al., 2013). Biochemical pesticides are derived from naturally occurring secondary plant metabolites (Archaya, 2014). These secondary plant metabolites such as terpenoids, flavonoids, quinines, and alkaloids are important in selfdefence mechanisms against herbivores and phytophagous insects (Belete, 2018). The possession of toxic secondary metabolites makes the plants and plant materials viable for use as biochemical pesticides (War et al., 2018). Kandungu et al. (2016) record some of the plants used as biopesticides in Kenya that include Zanha Africana, Vernonia amygadlina, Tithonia diversifolia, Tephrosia vogelii, Tanecetum cinerariiforium, Tagetes minuta, Strynchos spinosa, Solanum incanum, Lantana camara, Lippia javanica, Melia volkensii, Euphorbia tirucalli (Kandungu et al., 2013). This is about $0.19 \%$ of the 6293 indigenous plants found in Kenya (Zhou et al., 2017). This shows that research on plants that have pesticidal properties in the country has not been done exhaustively.

Globally several plant products have been registered as biochemical pesticides. Some biochemical pesticides already in the market include citrus oil (limonene, linolool), neem (Azadirachta), pyrethrins, Rotenone, Ryania, nicotine, and sabdilla (Sharma \& Malik, 2012). Despite vast information on biopesticides and global acceptance of biopesticide use, there is still low endeavour by farmers to use biopesticides (Constantine wt al., 2020). This is shown by the low penetration of biopesticides in the market as they contribute only $5 \%$ of the global pesticide market share worth the United States US \$ 3 billion (Ndolo et al., 2019). However, according to Global Forecast-2025 (2020), the global pesticide market is expected to grow at $14.7 \%$, estimated at US\$ 4.3 billion in 2020 to US\$ 8.3 billion by 2025 (Market Research, 2020). 
Kenya imports about 7000 metric tons of pesticide assortments worth US\$ 50 million annually, of this only $2 \%$ constitutes the biopesticides valued at US\$ 1 million (Birech, Freyer \& Macharia, 2006). This implies that only a few biopesticides have been registered for commercialisation in Kenya. Some botanical pesticides registered for commercial use in Kenya include Trilogy 70 EC® (neem oil) Flower DS EC® (Pyrthrins), Neemraj Super ${ }^{\circledR}$ (neem), NeemarkEC ${ }^{\circledR}$ (neem), Pyerin EC® (Pyrthrins), and Nimbecidine EC® (neem) (PCPB, 2018)

Aphis gosypii, Bemisia tabaci, and Thrips tabaci cause huge losses in agriculture, in Kenya Bemisia tabaci are major vectors of viral diseases, they reduce cassava (Manihot esculentum) yield by up to $40 \%$ and at times up to $100 \%$ (Njoroge et al., 2017), Thrips tabaci are found in all onion growing areas in Kenya and cause up to $59 \%$ loss in yield of onions (Allium cepa) (Waiganjo et al., 2007) Aphid can cause more than $90 \%$ of losses in wheat (Triticum aestivum $\mathrm{L}$ ) produce (Njuguna et al., 2016) . These pests are mainly controlled using chemical insecticides such as pyrethroids, organophosphates, nicotinic receptors agonists, insect growth regulators, carbamates, inorganic pesticides, and neonicotinoids (Thomas, 2018). However, from the documented negative effects of most synthetic pesticides, biopesticides have been sought after as an alternative globally (Auamcharoen \& Chandrapatya, 2015). Most biopesticides have a high potential for use in sustainable agriculture because most are reported to be environmentally benign, less toxic to human beings and non-target organisms, pest-specific, among others (Mazid, Kalita \& Rajkhowa, 2011). Plant-based biopesticides are among the most utilised alternatives to chemical pesticides globally. This study proposes to develop a biopesticide from Ocimum kenyense. Research shows that these plants contain essential oils that show some activities against plant pests; however, the blended oils extracted from these plants have not been tested against T. tabaci, B. tabaci, and A. gosypii (Hassanali et al., 1990).

\section{MATERIALS AND METHODS}

$5.000 \mathrm{~kg}$ of fresh leaves were collected during the rainy seasons when the plants were almost flowering as identified by Mr Patrick Mutiso, a taxonomist from the University of Nairobi. Flowers were deposited in the university of Nairobi herbarium under voucher specimen number as follows $O$. kenyense (JNM003/2021). Plant leaves $O$. kenyense plant were collected from Ngong forest Lan'gata road in Nairobi County, Kenya. The fresh leaves were weighed using a spring balance. They were rinsed with tap water to remove any physical are chemical impurities. The leaves were dried on the benches at the Mount Kenya Pharmacognosy Laboratories for seven days to a constant mass by losing $90 \%$ of the total moisture content. The total dry mass was weighed using an analytical grade balance Shimadzu ATY224 uniblock at the Pharmacy laboratory Mount Kenya University and the total dry mass of $0.5000 \mathrm{~kg}$ was recorded. The percentage moisture content lost was computed by the following formula

$$
\begin{aligned}
& \text { Percenatge moisture lost } \\
& =\frac{\text { mass of fresh leaves }- \text { mass of dry leaves }}{\text { mass of fresh leaves }}
\end{aligned}
$$

The dry plant leaves from $O$. kenyense, were pulverised using a kitchen blender at the Pharmacognosy laboratory in Mount Kenya University. The dry powdered plant materials were hydro distilled using the Clevenger apparatus for eight hours at $100^{\circ} \mathrm{C}$ and ambient atmospheric pressure. The vial was weighed had a mass of using Shimadzu ATY224 uniblock $17.964 \mathrm{~g}$ the vials and the oils were re-weighed and had a mass of $18.972 \mathrm{~g}$. The mass of essential oils was calculated by subtracting the mass of the vials from the mass of oils and the vials. The rate at which the oils were produced were computed $0.001 \mathrm{Kg}$ of essential oils $/ 0.2 \mathrm{Kg}$ of dry leaves

\section{ATR-FTIR and GC-MS Analysis of Ok Essential Oils}

The samples of $O$. kenyense were received at the Government Chemist Laboratory Department Nairobi County in Kenya and serialised under laboratory sample number F/MISC/188/2021 on $30^{\text {th }}$ April 2021.

\section{ATR- FTIR Analysis}

The essential oils from Ok, were analysed using an ATR-FTIR instrument and output in the form of a spectrum of the essential oil was obtained using Bruker spectrum Alpha 11 ATR-FTIR 1253-6069 spectrometer at the Government Chemist Department Laboratories in Nairobi County, Kenya. The ATR_FTIR used in this analysis was a single bounce ATR spectrophotometer where the IR radiation and the 
sample interact on the same plane. The functional groups were determined with the help of IR correlation charts in the computer libraries. The IR spectra were reported in \% transmittance and the fingerprint region was used to match the compounds. The wave number region for the analysis was $4000-500 \mathrm{~cm}^{-1}$ (in the mid-infrared range). Each molecule produced a unique spectrum that was used as a fingerprint for molecular identifications. Based on the ATRFTIR profiles of the essential oil samples, the natural products present were identified by ATRFTIR and subsequent comparison with the ATRLIB-PHARMA-2-472-2S01. The compounds with a hit quality of 600 and above as analysed by ATR-FTIR shows a high probability of being present in the essential oils.

\section{GC-MS Analysis}

$20.0 \mu \mathrm{L}$ of the crude essential oils samples were diluted using $1 \mathrm{~mL}$ of a mixture of $\mathrm{n}$-hexane and dichloromethane in the ratio of 1:4. The component identification was achieved by the GC-MS performed on the Agilent 5977A MSD and 7890B GC system, Chemetrix; Agilent Technologies, DE (Germany) at the Government Chemist Department Laboratories in Nairobi Kenya. Helium was used as carrier gas at a constant flow of $1 \mathrm{~mL} / \mathrm{min}$ and spitless. An injector volume of $1 \mu \mathrm{l}$ was employed with the mass spectra scanned from 40 to $560 \mathrm{~m} / \mathrm{z}$ at an injector temperature of $250{ }^{\circ} \mathrm{C}$. Ionisation was by electron impact $(70 \mathrm{eV}$, source temperature 250 $\left.{ }^{\circ} \mathrm{C}\right)$. The oven temperature was programmed from $50{ }^{\circ} \mathrm{C}$ (isothermal for $1 \mathrm{~min}$.), with an increase of $10{ }^{\circ} \mathrm{C} / \mathrm{min}$, to $300{ }^{\circ} \mathrm{C}$ and held for $3 \mathrm{~min}$, isothermal at $300{ }^{\circ} \mathrm{C}$. Total GC running time was $32 \mathrm{~min}$. Chromatographic separation was done using DP5-MS-UI. The components of essential oils were identified on the basis of comparison of their retention time and mass spectra with published data and computer matching with NIST11 and National Institute of Standards and Technology (NIST11) libraries ((NISTEPA, NISTDRUG, and NISTTOX) provided with the computer controlling the GC-MS system at the Government Chemist Department Laboratories, Nairobi. The spectrum of the unknown component was compared with the spectrum of the known components stored in the library. Peak areas were calculated and approximated using peak heights. The peak height is measured in $\mathrm{mm}$ and the heights are summed up, then percentages were computed. According to (Wang, 1997) here is a 0.9993 correlation between the peak height and the concentration of the components of the mixture. The GC-MS analysis results for each of the essential oils are described below.

\section{Contact Toxicity of $O$. kenyense against A. gosypii, T. tabaci and $B$. tabaci.}

Twenty pests from each species of $A$. gosypii, $T$. tabaci and B. tabaci were released on filter papers treated with acetone as the blank and replicated five times. The same step was repeated with filter papers different treated with different concentrations of essential oils $0.00,0.01,0.25$, 0.75 and $1.0 \mu \mathrm{L}$ of $O$. kenyense, T. diversifolia and $S$. manii and permethrin as the positive control in covered petri dishes. The responses to the treatments were observed after 24 hours. Probing was done using a blunt object and the pests that did not respond to probing were counted as dead. The data was then computed and transformed using SPSS version 26.0, analysed by Probit analysis to determine LD50.

\section{Repellency test for Essential oils from $O$. kenyense against $B$. tabaci, T. tabaci and $A$. gosypii.}

A repellency test (area preference test) was used to evaluate the repellent action of the essential oils. Test arenas consisted of $10.9 \mathrm{~cm}$ Whatman filter papers no. 1 cut into half. Test samples were prepared by dissolving $0.031,0.062,0.125$, and $0.251 \mu \mathrm{L}$ of the crude extracts of essential oils into 1 millilitre of acetone (Ngassoum et al., 2007). Each solution was applied to a half filter paper disc uniformly using a micropipette. The other filter paper halves were treated with acetone only. They were air-dried to evaporate the acetone completely. The treated and untreated half discs were then enjoined using cello tape and placed in Petri dishes. A commercial repellent containing 20-30\% DEET was used as a positive control and was applied on the filter papers as the essential oils (Wei et al., 2018). 10 pests of each species were released at the centre of the filter papers and the responses were observed after one hour.

\section{RESULTS}

\section{ATR-FTIR Analysis of Essential Oil Composition of $O$. kenyense Plant}

From the ATR-FTIR profiles of essential oils of $O$. kenyense, the following compounds were 
identified. However, only substances with hit quality above 600 had a higher probability of being present in the essential oils, that is Eucalyptus oil which has several constituents including $\alpha$-pinene, $p$-cymene, aphelland-rene, 1,8-Cineole, c-terpinene, and limonene and 1,8Cionele. The figure below shows the ATR-FTIR spectrum for $O$. kenyense essential oils

\section{Figure 1: ATR_FTIR spectrum of Ecalyptol}

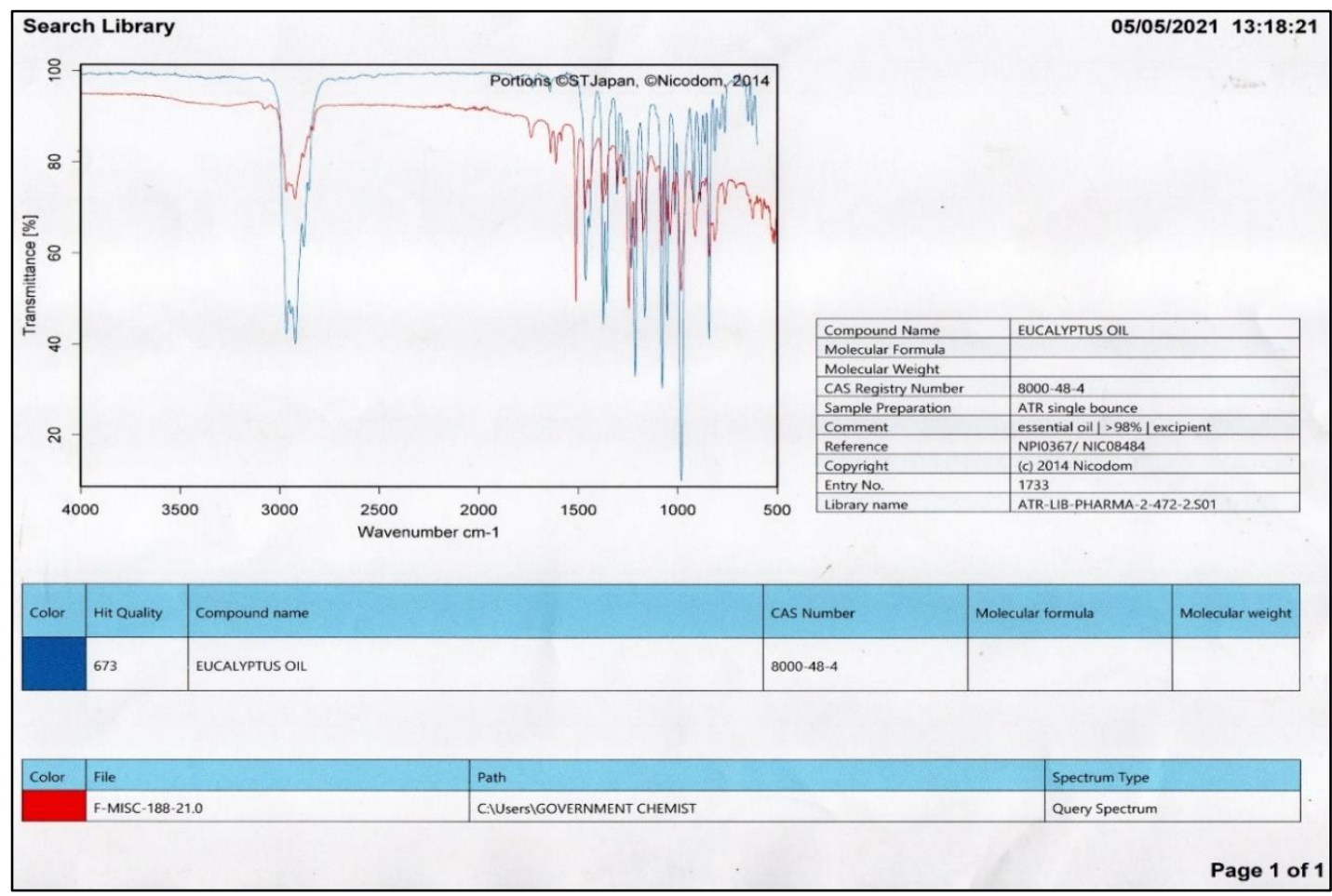

Figure 2: ATR-FTIR spectrum of 1,8-Cionele

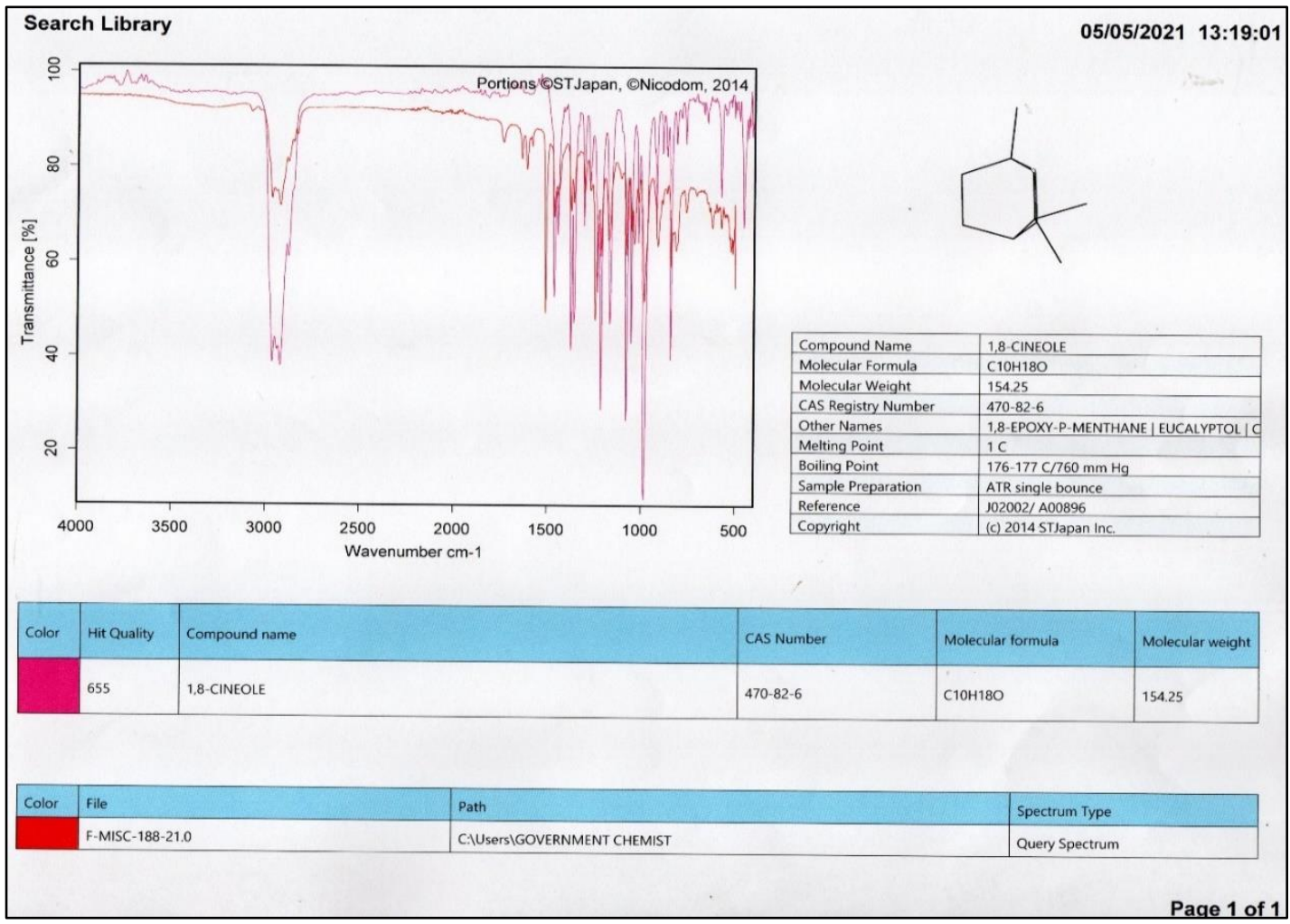

18 | This work is licensed under a Creative Commons Attribution 4.0 International License 
Table 1 below shows some chemical constituents as identified by comparison with ATR-LIBPHARMA-2-472-2S01 libraries

Table 1: Chemical constituents of the essential oil derived from O. kenyense ATR-FTIR

\begin{tabular}{lllll}
\hline $\begin{array}{l}\text { Compound } \\
\text { name }\end{array}$ & $\begin{array}{l}\text { Hit } \\
\text { quality }\end{array}$ & $\begin{array}{l}\text { Major peaks } \\
\text { Wave numbers }\end{array}$ & $\begin{array}{l}\text { Molecular } \\
\text { formula }\end{array}$ & Classification \\
\hline Eucalyptus oil & 673 & $2800 \mathrm{Cm}^{-1}$ & $\mathrm{~N} / \mathrm{A}$ & $\begin{array}{l}\alpha \text {-pinene, p-cymene, aphellandrene, } \\
1 \text {-carene, 1,8 cineole, c-terpinene, } \\
\text { and limonene }\end{array}$ \\
\hline 1,8 -Cionele & 655 & $2800 \mathrm{Cm}^{-1}$ & $\mathrm{C}_{10} \mathrm{H}_{18} \mathrm{O}$ & Monoterpene \\
\hline
\end{tabular}

The major peaks at $2800 \mathrm{Cm}^{-1}$ are be assigned to $\mathrm{C}-\mathrm{H}$ stretching bond for alkanes.

\section{Essential Oil Composition of O. kenyense Plant}

The essential oils from $O$. kenyense leaves revealed several peaks which represent different compounds, as shown in the total chromatogram by Gas Chromatography-Mass Spectrometry analysis. The peaks in the chromatogram were integrated and were compared with the database of the spectrum of known components stored in the Gas Chromatography-Mass Spectrometry library while the quantitation was approximated by peak heights. Gas Chromatography-Mass Spectrometry Analysis of the essential oils leaves revealed the presence of different terpenes, monoterpenes, sesquiterpenoids, and aromatic compounds. The figure below shows GC-MS spectrum of $O$. kenyense essential oils.

Figure 3: GC-MS analysis of $O$. kenyense essential oils

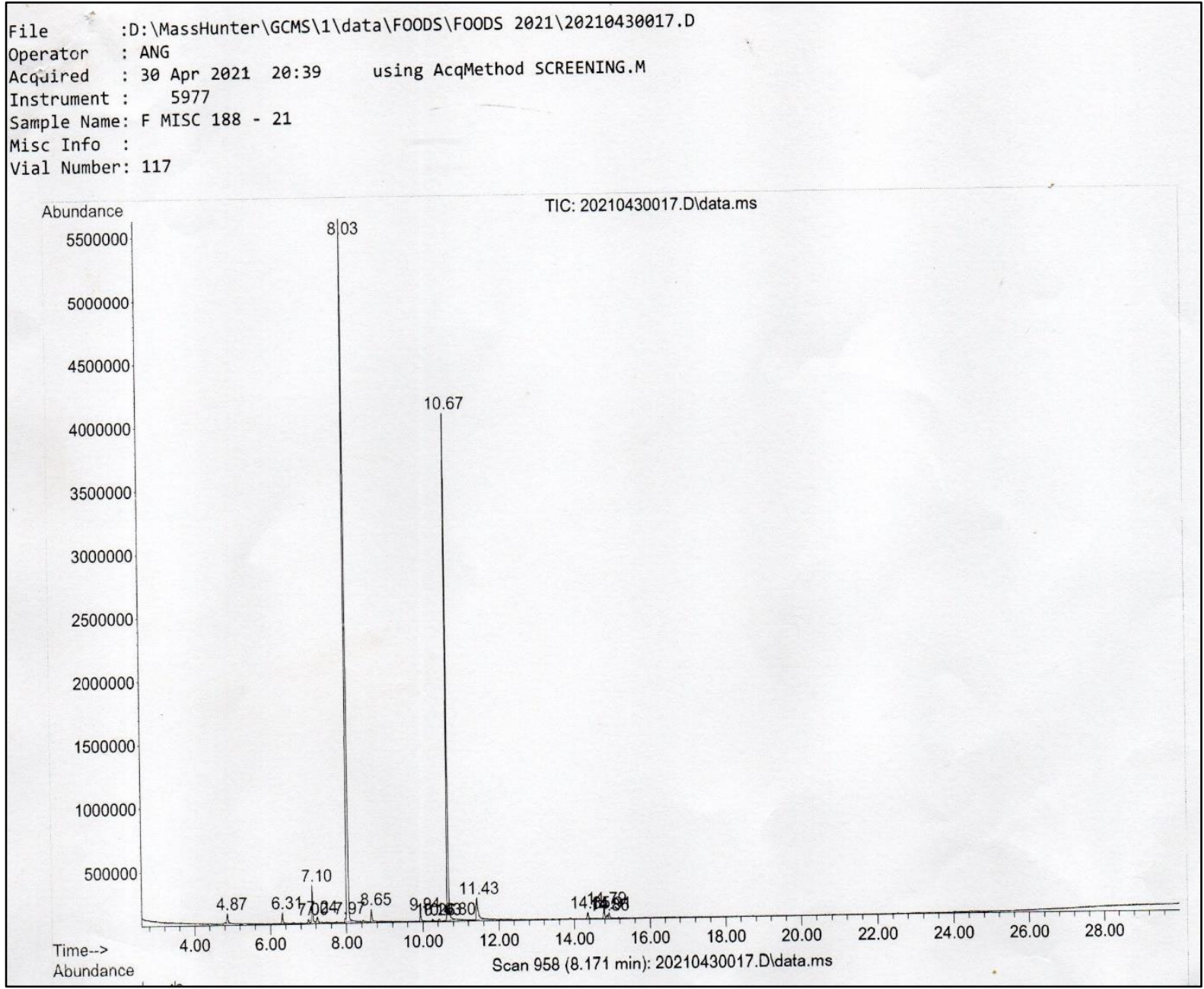

19 | This work is licensed under a Creative Commons Attribution 4.0 International License 
The results of GC-MS analysis are described in kenyense identified by GC-MS were drawn using table 4.8 below. The constituent compounds of $O$. chemsketch software

Table 2: Chemical constituents of the essential oil derived from O. kenyense by GC-MS

\begin{tabular}{|c|c|c|c|c|c|}
\hline $\begin{array}{l}\text { Compound } \\
\text { name }\end{array}$ & $\begin{array}{l}\text { Retention } \\
\text { time }\end{array}$ & Percentage & $\begin{array}{l}\text { Molecular } \\
\text { formula }\end{array}$ & Molecular structure & Classification \\
\hline $\begin{array}{l}\text { Eucalyptol } \\
(1,8- \\
\text { Cionele) }\end{array}$ & 8.03 & $55.7 \%$ & $\mathrm{C}_{10} \mathrm{H}_{18} \mathrm{O}$ & & $\begin{array}{l}\text { Oxygenated } \\
\text { Monoterpenoid }\end{array}$ \\
\hline Anisole & 10.6694 & $39.78 \%$ & $\mathrm{C}_{7} \mathrm{H}_{8} \mathrm{O}$ & & Aromatic \\
\hline 3-Carene & 7.1005 & $2.7 \%$ & $\mathrm{C}_{10} \mathrm{H}_{16}$ & $\overline{\mathrm{H}_{2} \mathrm{C}}$ & $\begin{array}{l}\text { Bicyclic } \\
\text { monoterpene }\end{array}$ \\
\hline Camphor & 9.9368 & $1 \%$ & $\mathrm{C}_{10} \mathrm{H}_{16} \mathrm{O}$ & & Terpene \\
\hline Terpenolene & 8.6521 & $0.53 \%$ & $\mathrm{C}_{10} \mathrm{H}_{16}$ & $\overline{\mathrm{H}} \mathrm{C}$ & Cyclic \\
\hline Junipene & 14.7851 & $0.26 \%$ & $\mathrm{C}_{15} \mathrm{H}_{24}$ & & Sesquiterpenoid \\
\hline
\end{tabular}


According to Bekele (1994), terpenoids are the most common essential oils and are classified as either monoterpenoid or sesquiterpenoids. This confirms the findings of this research since the majority of the essential oils obtained from $\mathrm{Ok}$, fell in the two classes of monoterpenoid and sesquiterpenoids. Terpenes are the most conspicuous plant secondary metabolites containing compounds that are inimical to phytophagous pests and herbivores. Besides playing a protective role against herbivory and phytophagy, they also contribute to the characteristic aroma in plants (Bekele, 1994). The essential oils $O$. kenyense were later tested against A. gosypii, T. tabaci and B. tabaci for contact toxicity and repellency action. The following section describes the results obtained from contact toxicity test and area preference test for repellency.

\section{LD50 of $O$. kenyense Oils against $A$. gosypii}

The data collected for mortality of the pest in contact with the $O$. kenyense essential oils was computed and transformed by Probit analysis using SPSS version 26.0 to determine LD50. LD50 for $A$. gosypii was calculated as $0.127 \mu \mathrm{L}$. The figure below represents a curve that was obtained from the Probit analysis.Figure 4: Probit analysis of $\boldsymbol{O}$. kenyense against $A$. gosypii

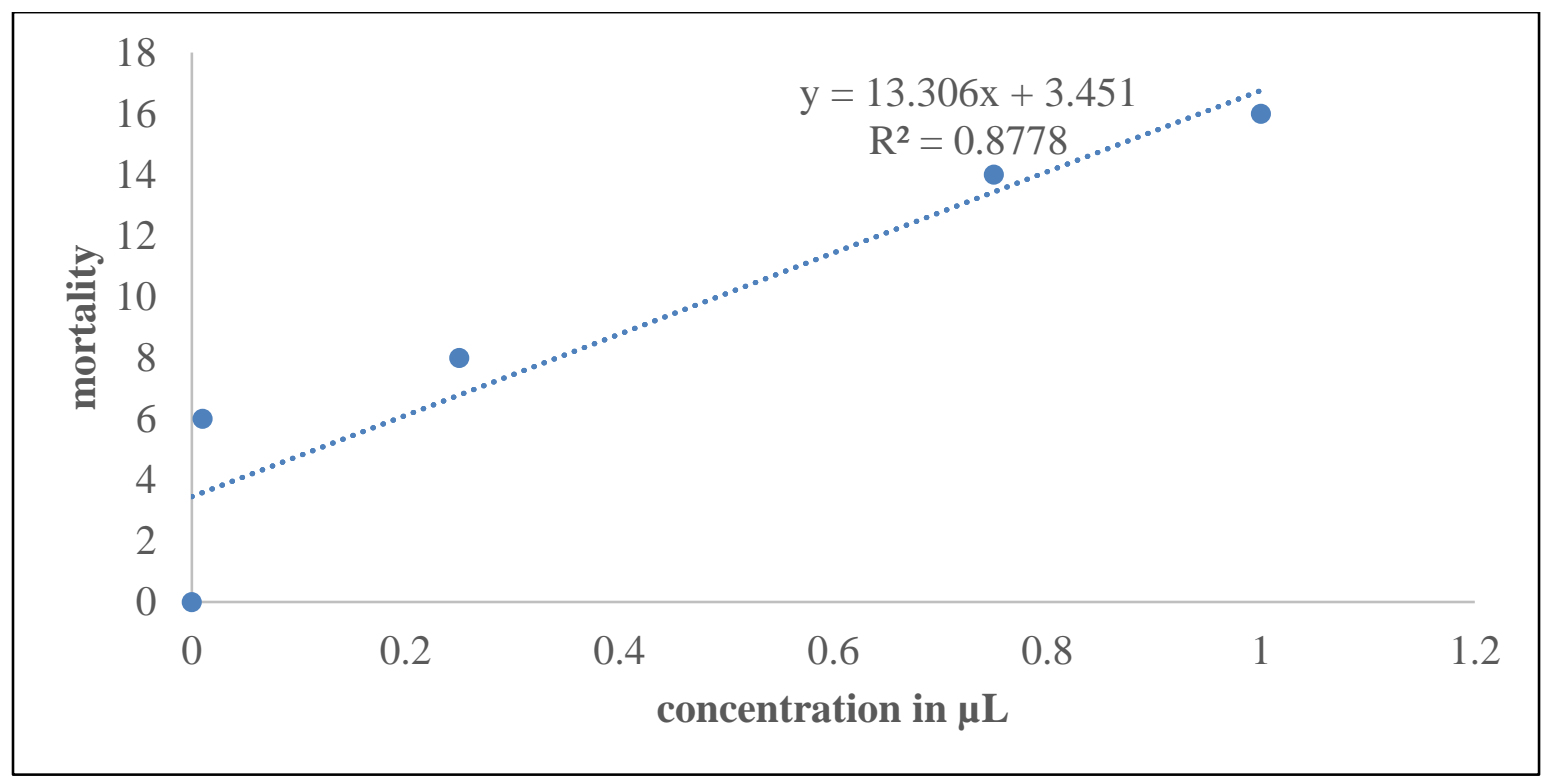

$\mathrm{R}^{2}=0.8778$, this shows there was a strong relationship between the increases in concentration and the percentage mortality of A. gosypii. As the concentration increases, the mortality percentage increased.

\section{LD50 of $O$. kenyense against T. tabaci}

LD50 for T. tabaci was calculated as $26.971 \mu \mathrm{L}$. The figure below represents a curve that was obtained from the Probit analysis. 
Figure 5: Probit analysis of $O$. kenyense essential oils against $T$. tabaci

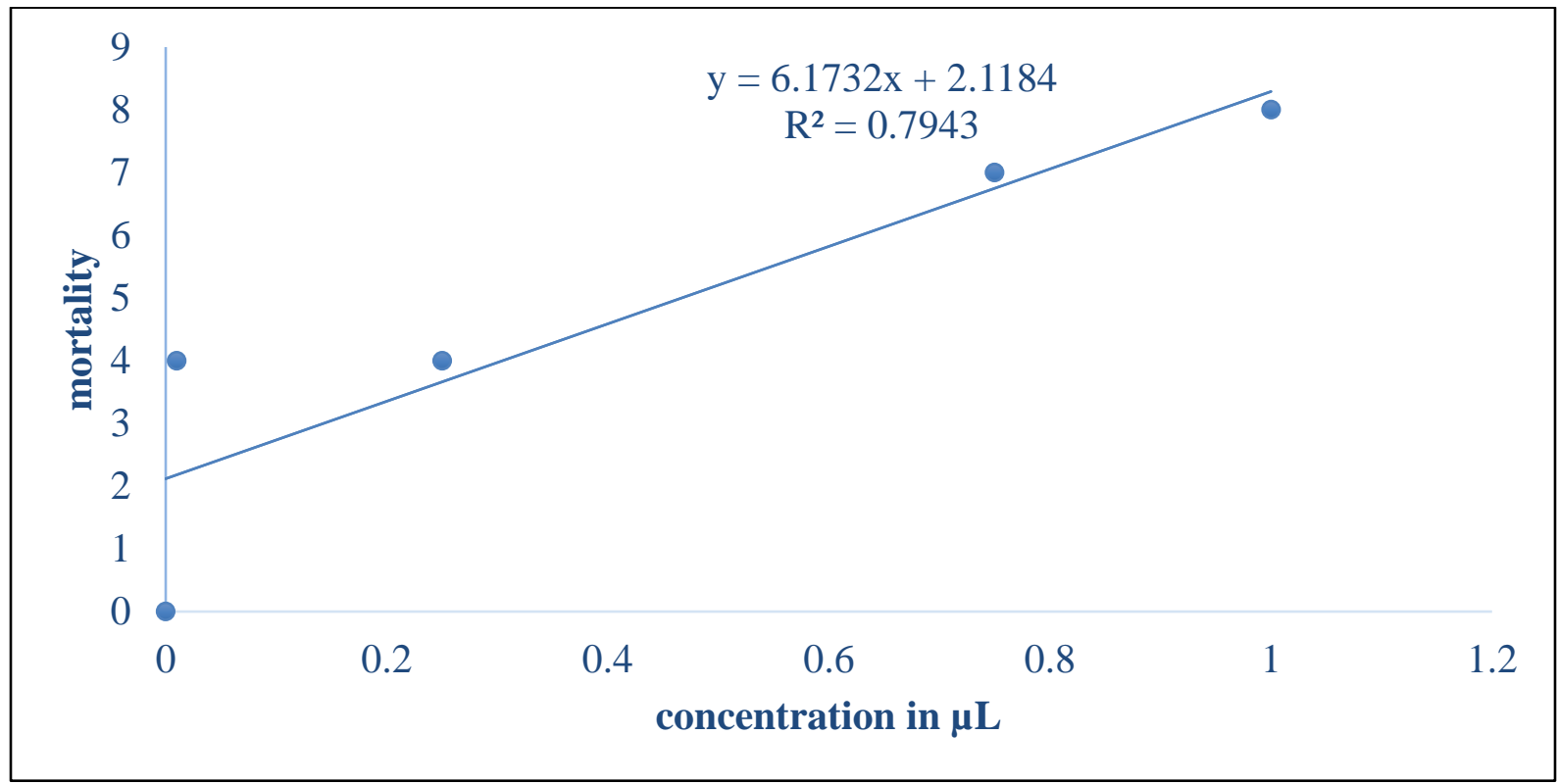

$\mathrm{R}^{2}=0.7943$ which shows there was a strong relationship between the increases the concentration and the percentage mortality. As the concentration increases, the mortality percentage increased.

\section{LD50 of $O$. kenyense against B. tabaci}

LD50 for B. tabaci was calculated as $2.229 \mu \mathrm{L}$. The figure below represents a curve that was obtained from the Probit analysis.

Figure 6: Probit analysis of $O$. kenyense against $B$. tabaci

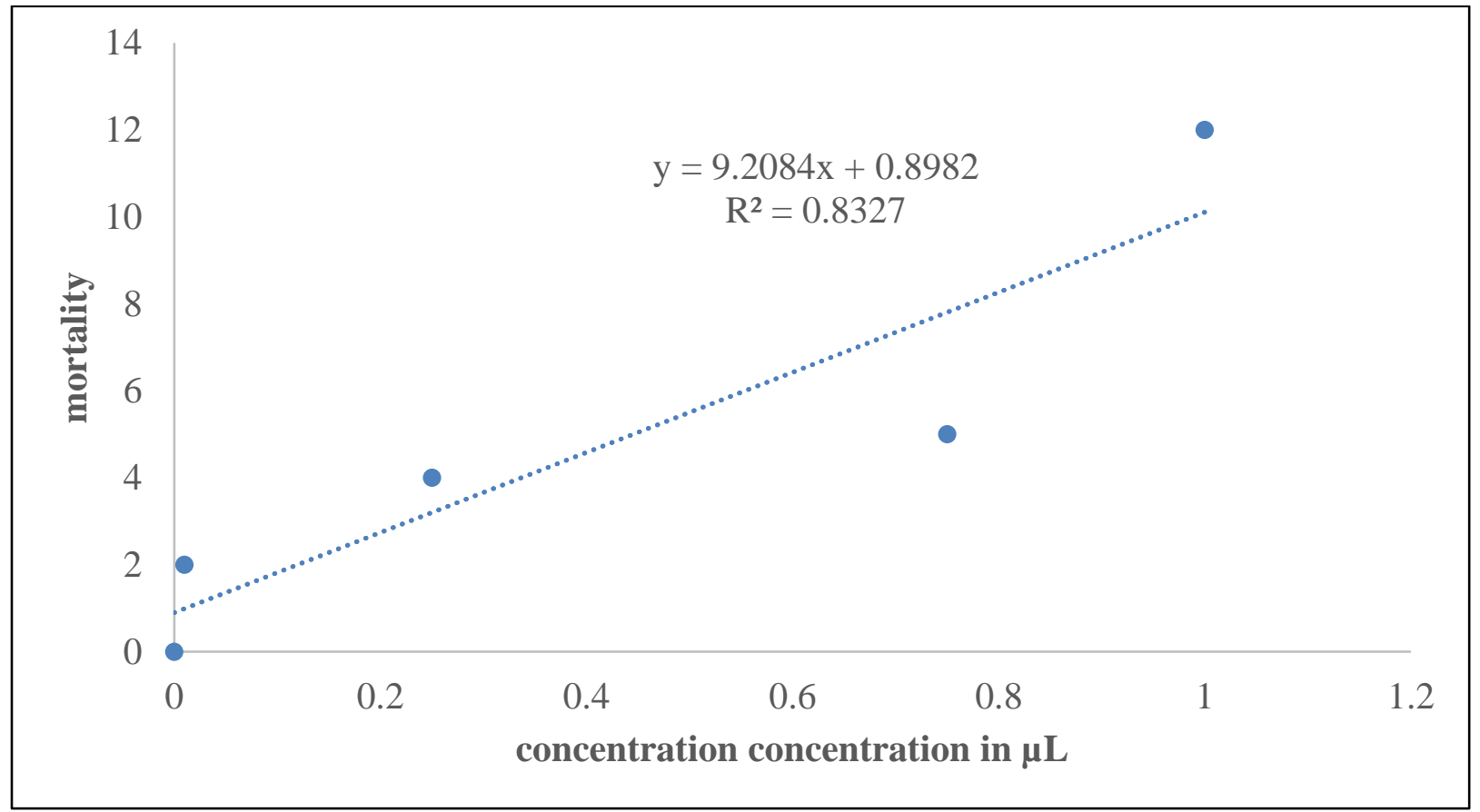

$\mathrm{R}^{2}=0.8327$ which shows there is a strong relationship between the increases the concentration and the mortality percentage. As the concentration increases, the mortality percentage increases.

$22 \mid$ This work is licensed under a Creative Commons Attribution 4.0 International License 
$O$. kenyense had the highest contact toxicity against A. gosypii as shown by a lower LD50 value of 0.127 $\mu \mathrm{L}$. The crude sample of the essential oils can be used in management of Aphis gosypii as contact toxicant.

Correlation Between the Percentage Repellency by Ok Essential Oils and the Concentration of Essential Oils

Correlation between the concentrations of $\mathrm{Ok}$ essential oils was computed using SPSS version
26.0 by Spearman's rho. There is a very high correlation between the increase in the concentration of Ok essential oils and the repellency percentage of A. glycine, T. tabaci and B. tabaci. Table 3 below shows the correlation between the concentration and the percentage repellency by $\mathrm{Ok}$ essential oils against the $\mathrm{Ag}, \mathrm{Tt}$ and $\mathrm{Bt}$. This implied that as the concentration of essential oils increased, the percentage repellency increased.

Table 3: The correlation between the concentration of $\mathrm{OK}$ and the percentage repellency of the pests

\begin{tabular}{llll}
\hline & & Concentration \\
\hline Spearman's rho & Percentage repellency of $O$. kenyense & Correlation Coefficient & $1.000^{* *}$ \\
& against $A$. gosypii & Sig. (2-tailed) &. \\
& & $\mathrm{N}$ & 4 \\
\cline { 2 - 4 } & percentage repellency of O. kenyense & Correlation Coefficient & $1.000^{* *}$ \\
against $T$. tabaci & Sig. (2-tailed) &. \\
& $\mathrm{N}$ & 4 \\
\cline { 2 - 4 } & percentage repellency of $O$. kenyense & Correlation Coefficient & $1.000^{* *}$ \\
against $B$. tabaci & Sig. (2-tailed) &. \\
& $\mathrm{N}$ & 4 \\
\hline
\end{tabular}

The results obtained were statistically significant and $(P<0.00$ and $\alpha=0.05)$. The repellency action data was presented using the figures below to show the estimated means of repellency against the concentration of essential oils.

Figure 7: Bar graph showing the mean mortality of $A$. gosypii against concentration of $O$. kenyense

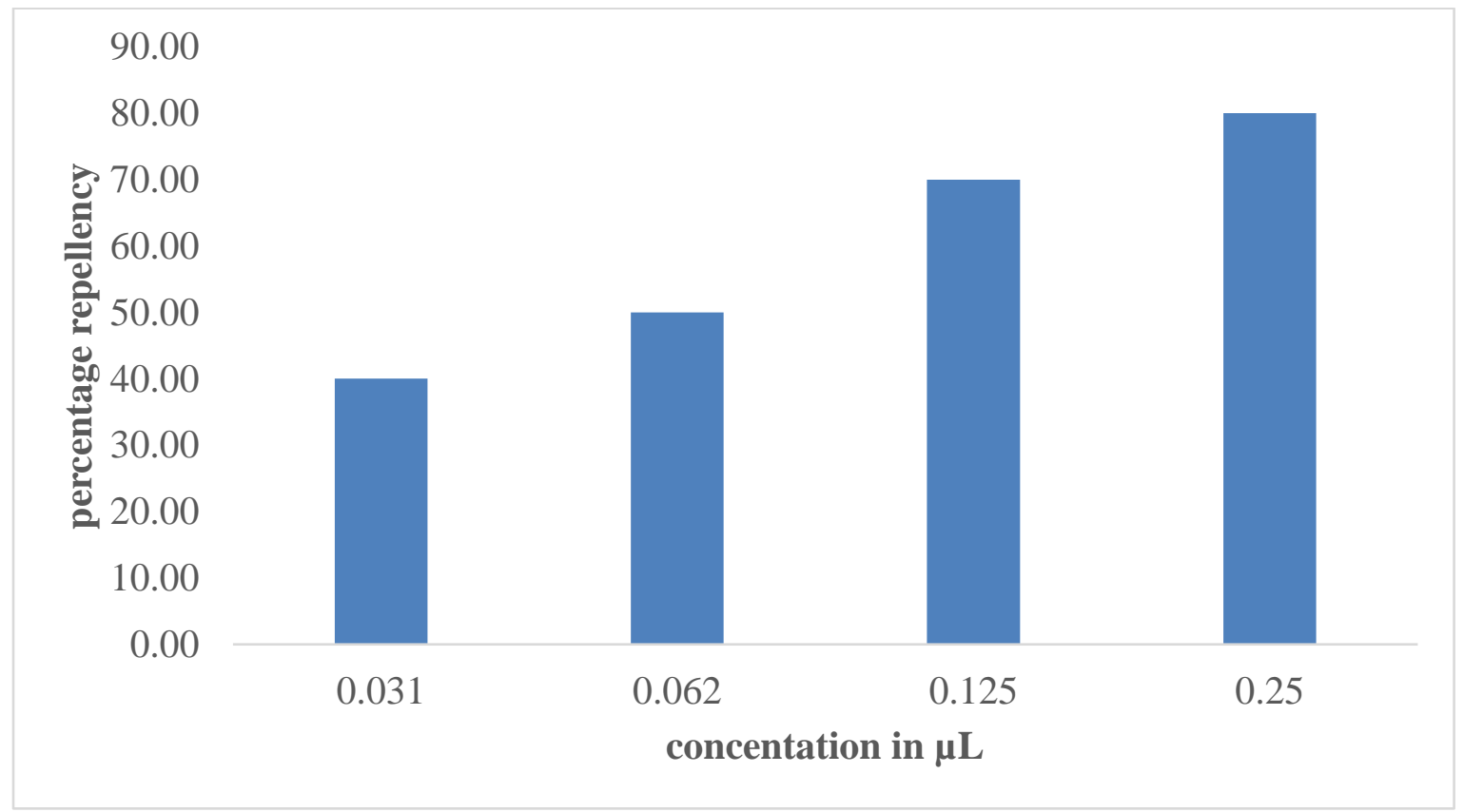

23 This work is licensed under a Creative Commons Attribution 4.0 International License 
Figure 8: Bar graph showing the mean mortality of $T$. tabaci against concentration of $O$. kenyense

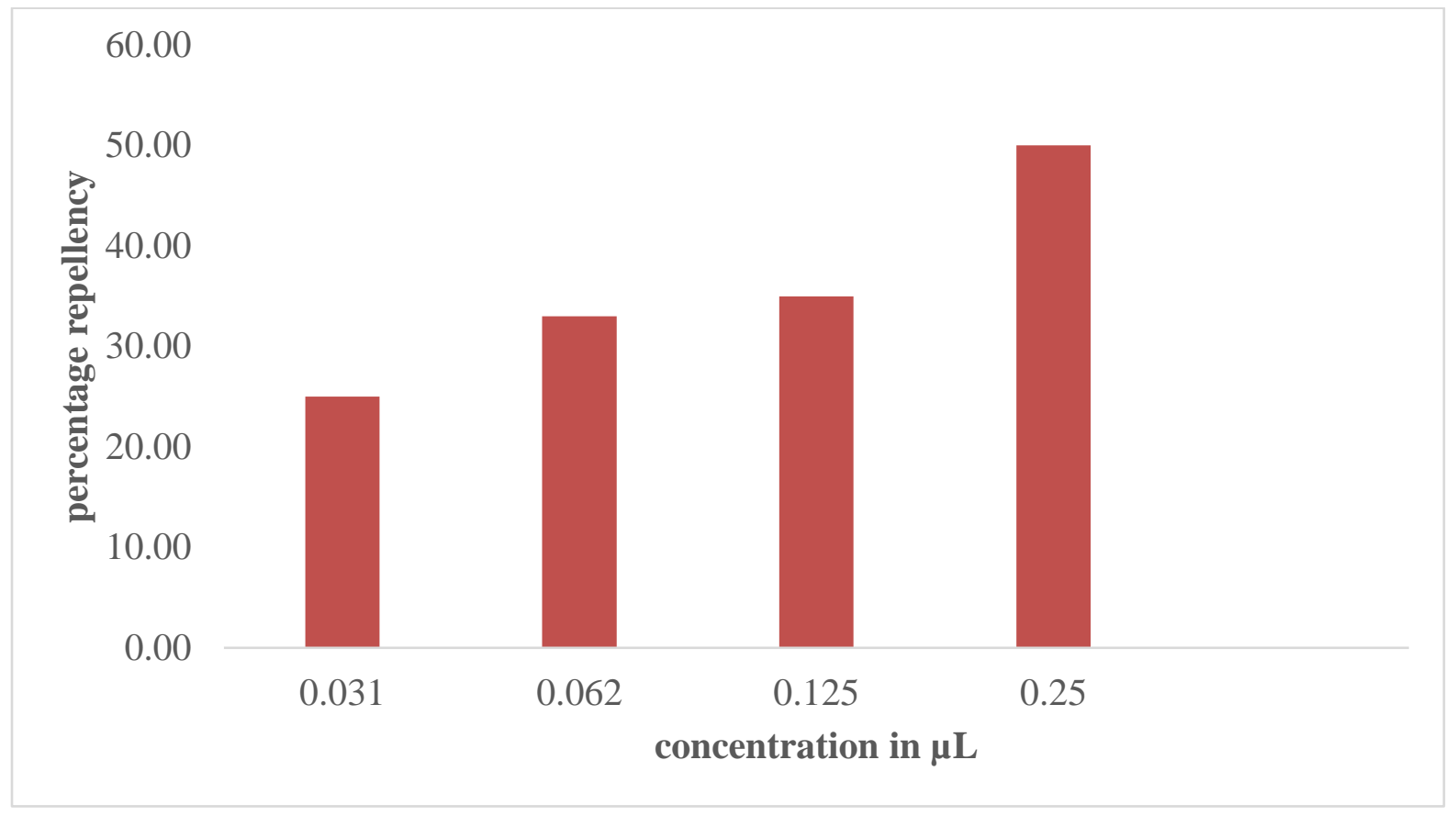

Figure 9: Bar graph showing the mean mortality of $B$. tabaci against concentration of $O$. kenyense

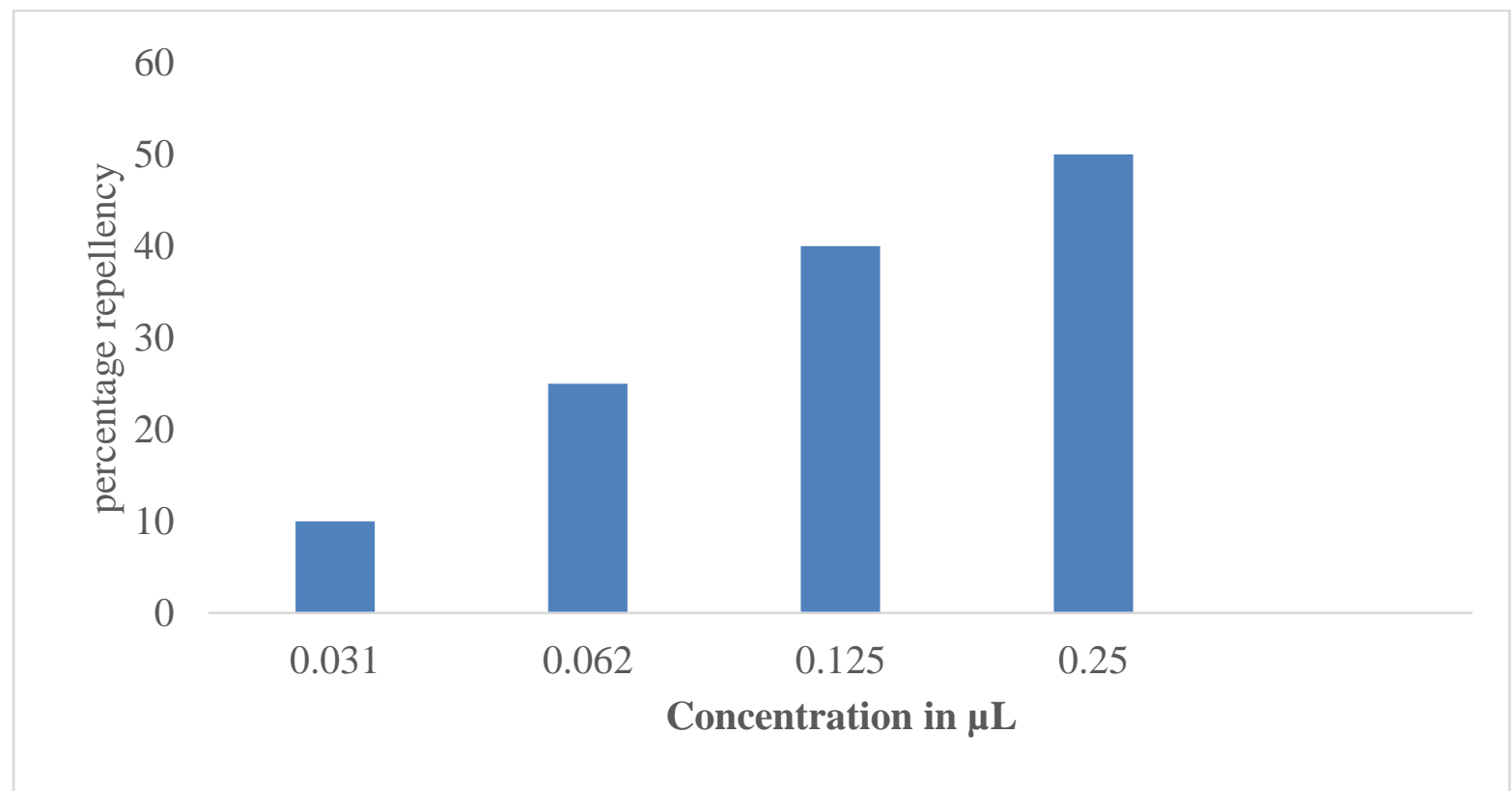

The estimated marginal means of the essential oils as analysed above shows that Ocimum kenyense attained the highest repellency against $A$. gosypii at $80 \%$, and a $50 \%$ repellency against both $B$. tabaci and $T$. tabaci and therefore a better repellent against A. gosypii.

\section{CONCLUSIONS}

The Ocimum kenyense essential oils were found to be more effective against $A$. gosypii than the $T$. tabaci and B. tabaci at an LD50 was $0.127 \mu \mathrm{L}$. This is because the essential oils were effective at lower concentrations. The oils were also found to have a

$24 \mid$ This work is licensed under a Creative Commons Attribution 4.0 International License 
higher repellency action against $A$. gosypii than $T$. tabaci and $B$. tabaci. The oils could therefore be used in effective management of $A$. gosypii than $T$. tabaci or $B$. tabaci by both contact toxicity and repellency action. The activity of the oils could be attributed to the presence of 1,8-cionelle, which is a leaf toxin with activity against predation by herbivores. 1, 8-cionelle is a cyclic terpene. The essential oils from $O$. kenyense have a high potential for use a contact toxicant biopesticide against $A$. gosypii and a repellent biopesticide against $A$. gosypii, T. tabaci and B. tabaci.

\section{ACKNOWLEDGEMENTS}

I would like to acknowledge the laboratory staff at the Government chemist and Mount Kenya University Pharmacy lab. Dr Mary Muriuki and Dr. Samuel Karenga for academic guidance And Mentorship.

\section{Declaration of Competing Interest}

The authors declare that there are no known competing financial interests or personal relationships that could have appeared to influence the work reported in this paper.

\section{REFERENCES}

Archaya, S. (2014). Bioremediation of pesticide polluted soil by organic farming practices of kolli hills Tamil Nadu India. Periyar University.

Auamcharoen, W., \& Chandrapatya, A. (2015). Acaricidal and ovicidal efficacies of Leucaena glauca Benth. seed crude extracts on Tetranychus urticae Koch (Acari: Tetranychida e). Journal of Biopesticides, 8(2), 68.

Bekele, J. A. (1994). Effects and use of some Ocimum plant species and their essential oils on some storage insect pests (Doctoral dissertation, University of Nairobi.).

Belete, T. (2018). Defense mechanisms of plants to insect pests: From morphological to biochemical approach. Trends Tech. Sci. Res, 2, 30-38.

Birech, R., Freyer, B., \& Macharia, J. (2006). Towards reducing synthetic pesticide imports in favor of locally available botanicals in Kenya.
Tropentag 2006 October 11-13 Conference on International Agricultural Research for Development. Bonn, Germany

Constantine, K. L., Kansiime, M. K., Mugambi, I., Nunda, W., Chacha, D., Rware, H., ... \& Day, R. (2020). Why don't smallholder farmers in Kenya use more biopesticides? Pest management science, 76(11), 3615-3625.

Gogi, M. D., Nawaz, A., Sufyan, M., Sarfraz, R. M., \& Liburd, O. E. (2017). Biorational approaches in pest management. Sustainable Insect Pest Management, 231-233.

Hassanali, A., Lwande, W., Ole-Sitayo, N., Moreka, L., Nokoe, S., \& Chapya, A. (1990). Weevil repellent constituents of Ocimum suave leaves and Eugenia caryophyllata cloves used as grain protectants in parts of Eastern Africa. Discovery and Innovation, 2(2), 91-95.

Ivase, T. J. P., Nyakuma, B. B., Ogenyi, B. U., Balogun, A. D., \& Hassan, M. N. (2017). Current Status, Challenges and Prospects of Biopesticide Utilization in Nigeria. Acta Universitatis Sapientiae, Agriculture and Enviroment, 9, 95106.

Kandungu, J., Anjarwalla, P., Mwaura, L., Ofori, D. A., Jammadass, R., Stevenson, P. C., \& Smith, P. (2013). Pesticidal Plant Leaflet. Tithonya diversifolia (Hemsley) A. Gray. Kew Royal Botanic Gardens, World Agroforestry Centre.

Kareru, P., Rotich, Z. K., \& Maina, E. W. (2013). Use of botanicals and safer insecticides designed in controlling insects: the African case. Insecticides-Development of Safer and More Effective Technologies, 10, 297-309.

Kavit, M. \& Jain, B. (2013). Phytochemical analysis of leaf extract of Phyllanthus fraternus. Research Journal of Recent Sciences, 2(ISC-2012), 12-15.

Kumar, S. (2012). Biopesticides: a need for food and environmental safety. $J$ Biofertil Biopestic, 3(4), 1-3.

Market Research. (2020). Biopesticides Market by Type (Bioinsecticides, Biofungicides, Bionematicides, and Bioherbicides), Source (Microbials, Biochemicals, and Beneficial 
Insects), Mode of Application, Formulation, Crop Application, and Region - Global Forecast to 2025. MarketsandMarkets

Mazid, S., Kalita, J. C., \& Rajkhowa, R. C. (2011). A review on the use of biopesticides in insect pest management. Int J Sci Adv Technol, 1(7), 169-178.

Ndolo, D., Njuguna, E., Adetunji, C. O., Harbor, C., Rowe, A., Den Breeyen, A., ... \& Hospet, R. (2019). Research and development of biopesticides: challenges and prospects. Outlooks on Pest Management, 30(6), 267-276.

Ngassoum, M. B., Tinkeu, L. S. N., Ngatanko, I., Tapondjou, L. A., Lognay, G., Malaisse, F., \& Hance, T. (2007). Chemical composition, insecticidal effect and repellent activity of essential oils of three aromatic plants, alone and in combination, towards Sitophilus oryzae L. (Coleoptera: Curculionidae). Natural Product Communications, 2(12), $1934578 X 0700201207$.

Njoroge, M. K., Mutisya, D. L., Miano, D. W., \& Kilalo, D. C. (2017). Whitefly species efficiency in transmitting cassava mosaic and brown streak virus diseases. Cogent Biology, 3(1), 1311499.

Njuguna, M. N., Mwangi, M. M., Kamundia, J. K., Koros, I., \& Ngotho, G. (2016). Cultural management of Russian wheat aphid infestation of bread wheat varieties in Kenya. African Crop Science Journal, 24(1), 101-107.

Pandya, I. Y. (2018). Pesticides and their applications in agriculture. Asian $J$ Appl Sci Technol, 2(2), 894-900.

Pest Control Products Board (PCPB). (2018). Pest Control Products Registered for Use in Kenya. Nairobi, KE: Pest Control Products Board.

Sharma, S., \& Malik, P. (2012). Biopestcides: Types and Applications. International Journal of Advances in Pharmacy, Biology and Chemistry, 1(4), 508-515.

Thomas M, G. B. (2018). Sustainable Management of arthropd pest of Tomato. London -United
Kingdom: Academic Press is an imprint of Elsevier.

Waiganjo, M. M., Muriuki, J., \& Mbugua, G. W. (2006, December). Potential of indigenous leafy vegetables as companion crops for pest management of high-value legumes: a case study of Gynandropsis gynandra in Kenya. In I International Conference on Indigenous Vegetables and Legumes. Prospectus for Fighting Poverty, Hunger and Malnutrition 752 (pp. 319-321).

War, A. R., Taggar, G. K., Hussain, B., Taggar, M. S., Nair, R. M., \& Sharma, H. C. (2018). Plant defence against herbivory and insect adaptations. AoB Plants, 10(4), ply037.

Wei, X. M., Guo, S. S., Yan, H., Cheng, X. L., Wei, F., \& Du, S. S. (2018). Contact toxicity and repellency of the essential oil from Bupleurum bicaule helm against two stored product insects. Journal of Chemistry, 2018.

Zhou, Y., Liu, B., Mbuni, Y., Yan, X., Mwachala, G., Hu, G., \& Wang, Q. (2017). Vascular flora of Kenya, based on the Flora of Tropical East Africa. PhytoKeys, (90), 113. 